\title{
Potassium (K) for Citrus Trees ${ }^{1}$
}

\section{Mongi Zekri and Tom Obreza ${ }^{2}$}

This publication is part of a series about understanding nutrient requirements for citrus trees. For the rest of the series, visit http://edis.ifas.ufl.edu/ topic_series_citrus_tree_nutrients.

To maintain a viable citrus industry, Florida growers must consistently and economically produce large, highquality fruit crops from year to year. Efficiently producing maximum yields of high-quality fruit is difficult without understanding soil and nutrient requirements of bearing citrus trees. Most Florida citrus is grown on soils inherently low in fertility with low cation exchange capacity (CEC) and low water-holding capacity, thus soils are unable to retain sufficient quantities of available plant nutrients against leaching caused by rainfall or excessive irrigation.

Seventeen elements are considered necessary for the growth of green plants: carbon $(\mathrm{C})$, hydrogen $(\mathrm{H})$, oxygen $(\mathrm{O})$, nitrogen $(\mathrm{N})$, phosphorus $(\mathrm{P})$, potassium $(\mathrm{K})$, magnesium $(\mathrm{Mg})$, calcium $(\mathrm{Ca})$, sulfur $(\mathrm{S})$, manganese $(\mathrm{Mn})$, zinc $(\mathrm{Zn})$, iron $(\mathrm{Fe})$, copper $(\mathrm{Cu})$, boron $(\mathrm{B})$, chlorine $(\mathrm{Cl})$, molybdenum (Mo), and nickel (Ni). Plants obtain $\mathrm{C}, \mathrm{H}$, and $\mathrm{O}$ from carbon dioxide and water. The remaining elements, called the "mineral nutrients," are obtained from the soil. Mineral nutrients are classified as macronutrients and micronutrients. The term "macronutrients" refers to those elements that plants require in large amounts $(\mathrm{N}, \mathrm{P}, \mathrm{K}, \mathrm{Mg}, \mathrm{Ca}$, and $S)$. The term "micronutrients" applies to plant nutrients that are essential to plants but are needed only in small amounts ( $\mathrm{Mn}, \mathrm{Zn}, \mathrm{Fe}, \mathrm{Cu}, \mathrm{B}, \mathrm{Cl}, \mathrm{Mo}$, and $\mathrm{Ni}$ ). This publication reviews the potassium $(\mathrm{K})$ requirements of citrus trees.

\section{Introduction}

Potassium (K) is one of the most important nutrients applied as fertilizer in Florida citrus groves. Potassium (also called potash) is listed on the fertilizer label as $\mathrm{K}_{2} \mathrm{O}$. Potassium plays a key nutritional role in determining yield, fruit size, and quality. The sandy soils used to produce citrus in Florida are naturally low in $\mathrm{K}$. Also, $\mathrm{K}$ is not fixed and does not accumulate in those sandy soils, even with repeated fertilizer applications. Thus, $\mathrm{K}$ fertilizer application is required every year in Florida citrus groves. Potassium deficiency is not common when a grove is fertilized normally, but deficiency can develop on high $\mathrm{pH}$ soils or when high $\mathrm{N}$ rates stimulate high fruit production.

If leaf $\mathrm{K}$ is consistently less than optimum from year to year, increase the $\mathrm{K}_{2} \mathrm{O}$ rate by $25 \%$. Low leaf $\mathrm{K}$ concentrations are common in groves planted on calcareous soils. If low yield, small fruit, fruit splitting, and/or creasing are observed, application of additional $\mathrm{K}$ fertilizer is justified. If trees do not respond to $\mathrm{K}$ soil application, an alternative approach to increasing leaf $\mathrm{K}$ is foliar sprays of potassium nitrate $\left(\mathrm{KNO}_{3}\right)$ or monopotassium phosphate (MKP), $\left(\mathrm{KH}_{2} \mathrm{PO}_{4}\right)$. Take precautions to avoid foliar burn from high spray concentrations. Fruit burn was not observed when $25 \mathrm{lbs}$ $\mathrm{KNO}_{3}$ /acre were applied in $125 \mathrm{gal}$ of water/acre, $15 \mathrm{lbs}$ $\mathrm{MKP} / \mathrm{acre}$ were applied in $32.5 \mathrm{gal}$ of water/acre, or when $15 \mathrm{lbs} \mathrm{MKP} / \mathrm{acre}$ were applied in 10 gal of water/acre by airplane.

1. This document is SL381, one of a series of the Department of Soil and Water Science, UF/IFAS Extension. A version of this article was previously published in Citrus Industry magazine. Original publication date: July 2013. Visit the EDIS website at http://edis.ifas.ufl.edu.

2. Mongi Zekri, multicounty citrus UF/IFAS Extension agent; and Tom Obreza, professor and interim associate dean for Extension; UF/IFAS Extension, Gainesville, FL 32611. 
Table 1. Guidelines for interpretation of orange tree leaf K (\%) analysis based on 4- to 6-month-old spring flush leaves from non-fruiting twigs

\begin{tabular}{|l|l|l|l|l|l|}
\hline & Deficient & Low & Optimum & High & Excessive \\
\hline Potassium & $<0.7$ & $0.7-1.1$ & $1.2-1.7$ & $1.8-2.4$ & $>2.4$ \\
\hline
\end{tabular}

Table 2. Apply $\mathrm{K}$ fertilizer at a $\mathrm{K}_{2} \mathrm{O}$ rate equal to the $\mathrm{N}$ rate.

\begin{tabular}{|l|l|}
\hline $\begin{array}{l}\text { Tree } \\
\text { age }\end{array}$ & $\begin{array}{l}\text { Pounds of } \mathrm{K}_{2} \mathbf{O} / \\
\text { tree/year } \\
\text { (range) }\end{array}$ \\
\hline 1 & $0.15-0.30$ \\
\hline 2 & $0.30-0.60$ \\
\hline 3 & $0.45-0.90$ \\
\hline
\end{tabular}

Table 3. Apply $\mathrm{K}$ fertilizer at a $\mathrm{K}_{2} \mathrm{O}$ rate equal to the $\mathrm{N}$ rate.

\begin{tabular}{|l|l|l|l|}
\hline Tree age & Oranges & Grapefruit & $\begin{array}{l}\text { Other } \\
\text { cultivars }\end{array}$ \\
\hline & \multicolumn{2}{|c|}{ Pounds of $\mathbf{K}_{2} \mathbf{O} /$ acre/year (range) } \\
\hline $4-7$ & $120-200$ & $120-160$ & $120-200$ \\
\hline 8 and up & $\begin{array}{l}140-250 \\
\text { Yield } \\
\text { based }\end{array}$ & $120-160$ & $\begin{array}{l}120-300 \\
\text { Yield } \\
\text { based }\end{array}$ \\
\hline
\end{tabular}

\section{Potassium Functions}

Citrus fruits remove large amounts of $\mathrm{K}$ compared to other nutrients. Potassium moves from leaves to fruit and seeds as they develop. Potassium is necessary for several basic physiological functions such as the formation of sugars and starch, synthesis of proteins, normal cell division and

Table 4. Effects of K on citrus fruit quality

\begin{tabular}{|c|c|}
\hline Variable & Rating \\
\hline \multicolumn{2}{|c|}{ Juice Quality } \\
\hline Juice Content & - \\
\hline Soluble Solids (SS) & - \\
\hline Acid $(A)$ & + \\
\hline SS/A Ratio & - \\
\hline Juice Color & - \\
\hline Solids/Box & - \\
\hline Solids/Acre & + \\
\hline \multicolumn{2}{|c|}{ External Fruit Quality } \\
\hline Size & + \\
\hline Weight & + \\
\hline Green Fruit & + \\
\hline Peel Thickness & + \\
\hline \multicolumn{2}{|c|}{ Increase (+), Decrease (-) } \\
\hline
\end{tabular}

growth, and neutralization of organic acids. Potassium is important in fruit formation and enhances fruit size, flavor, and color. This nutrient also helps to reduce the influence that adverse weather conditions (such as drought, cold, and flooding) have on citrus trees.

Potassium is known to influence many enzymatic reactions and is associated with almost every major plant function. Potassium helps to regulate the carbon dioxide supply to plants by controlling stomata opening and closing. It improves the efficiency of plant water and sugar use for maintenance and normal growth functions. Additionally, $\mathrm{K}$ moves sugars from the site of photosynthesis to other storage sites. Potassium works with phosphorus $(\mathrm{P})$ to stimulate and maintain rapid root growth of plants and stimulates the synthesis of protein from amino acids. Potassium improves plant health, disease resistance, and tolerance to nematodes and insects. The rate of photosynthesis drops sharply when plants are $\mathrm{K}$ deficient.

\section{Potassium Deficiency}

The rate of photosynthesis drops sharply when plants are $\mathrm{K}$ deficient. Too much $\mathrm{N}$ with too little $\mathrm{K}$ can result in a backup of the protein building blocks, set the stage for disease problems, reduce production of carbohydrates, reduce fruiting, and increase fruit splitting, fruit creasing, plugging, and drop. K shortage can result in decreased yield and low fruit quality. Negative effects of low K generally occur on fruit yield and quality before leaf deficiency symptoms. Decreased yield and small fruit have been observed on trees with leaf $\mathrm{K}$ in the range of $0.5 \%-0.8 \%$, while $\mathrm{K}$ concentrations of $1.2 \%$ or more have been associated with maximum yield of high-quality fruit. Moderately low concentrations of $\mathrm{K}$ in the tree cause a general reduction in growth without

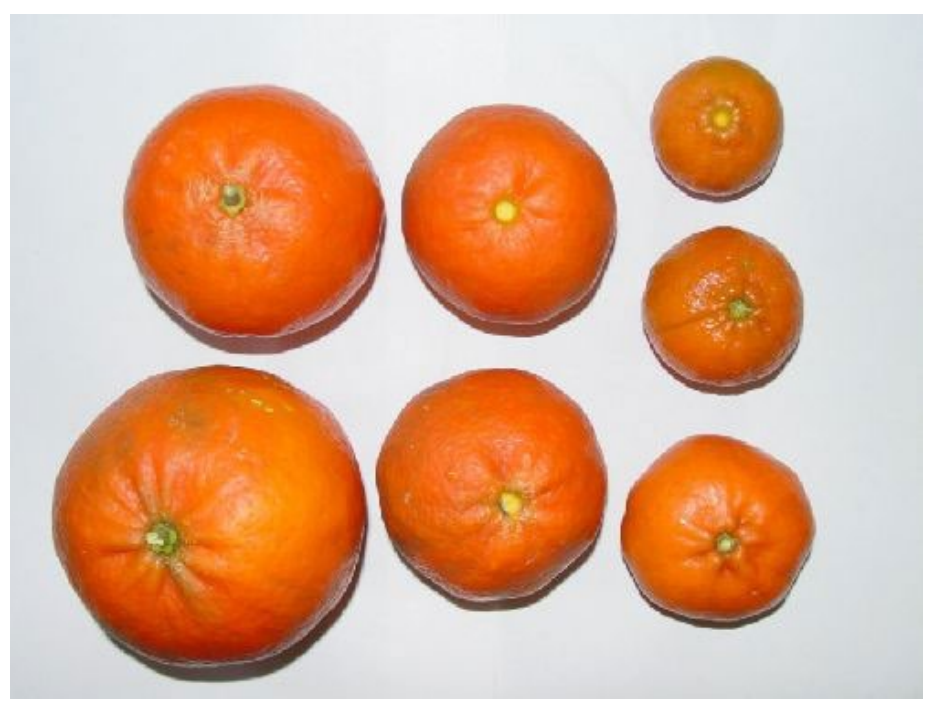

Figure 1. One symptom of potassium deficiency is small fruit. Credits: M. Zekri 


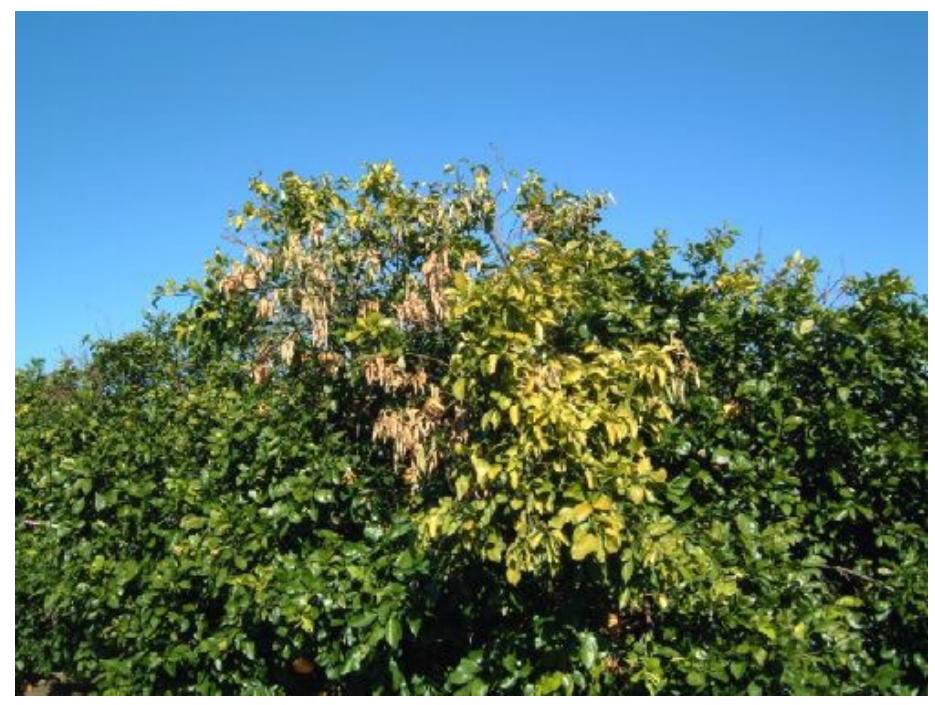

Figure 2. This citrus tree shows chlorosis and necrotic spotting of leaves, both symptoms of a K deficiency. Credits: T. Obreza

visual deficiency symptoms. The onset of visual deficiency symptoms means that production has already been seriously impaired.

In Florida, low $\mathrm{K}$ fertilization can lead to deficiency symptoms developing on the recently matured spring flush leaves in the late summer and fall. When $\mathrm{K}$ is low, the general leaf pattern begins as a yellowing of the tips and margins, which then gets broader. Necrotic areas and spotting can develop on the leaves. Symptoms appear first on older leaves because $\mathrm{K}$ tends to concentrate in the rapidly growing tissues. Potassium deficiency causes slow vegetative growth, small leaves, fine branches, thin canopy, increased susceptibility to drought and cold, reduced fruit size, very thin peel of smooth texture, premature shedding of fruit, and lower acid concentration in the fruit.

Potassium deficiency symptoms usually result from an insufficient $\mathrm{K}$ supply in the soil. Potassium deficiency may occur on acid sandy soils where leaching may be considerable. The supply of $\mathrm{K}$ to plants may be decreased by soils that have very high concentrations of $\mathrm{Ca}$ and $\mathrm{Mg}$ or by heavy $\mathrm{N}$ application. Decreased K uptake is typical on some calcareous soils. Lack of soil moisture also reduces $\mathrm{K}$ uptake and may lead to $\mathrm{K}$ deficiency. If the supply of $\mathrm{N}$ and $\mathrm{P}$ is high relative to that of $\mathrm{K}$, growth may be rapid at first, but the $\mathrm{K}$ concentration in the plant may ultimately decrease to cause deficiency. Addition of $\mathrm{K}$ is necessary to maintain the nutrient balance required for uniform and continued growth. In situations where available $\mathrm{K}$ is high compared to the $\mathrm{N}$ or $\mathrm{P}$ supply, luxury consumption of $\mathrm{K}$ can occur.

Under most soil conditions, $\mathrm{K}$ deficiency can be corrected by applying potassium chloride (muriate of potash) or potassium sulfate to the soil. However, in fine-textured, saline,

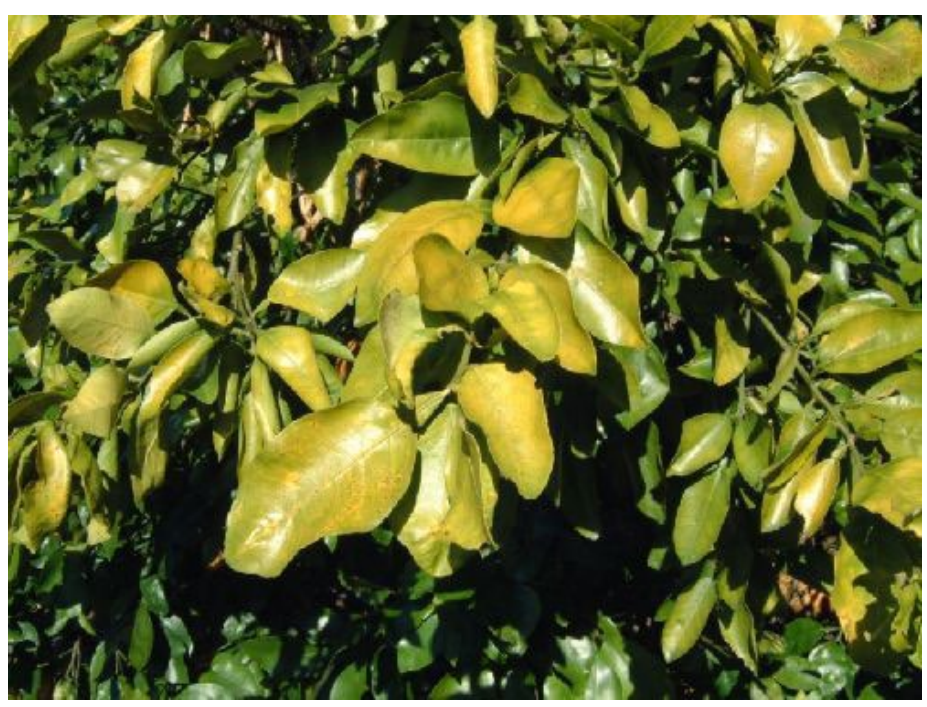

Figure 3. These citrus leaves show K-deficiency symptoms, including chlorosis and necrotic spotting of leaves. Credits: T. Obreza

or calcareous soils, $\mathrm{K}$ applications to the soil are sometimes ineffective or slow to correct K deficiency. Foliar application of potassium nitrate or mono-potassium phosphate can be very effective and rapid to correct $\mathrm{K}$ deficiency. The recommended foliar $\mathrm{K}$ spray for mature citrus trees is $8 \mathrm{lbs}$ $\mathrm{K}_{2} \mathrm{O}$ /acre per application. Foliar spray application of $\mathrm{K}$ has been demonstrated to increase fruit size. Foliar-applied K has also corrected $\mathrm{K}$ deficiency of citrus on calcareous soil. Foliar application of potassium nitrate $\left(\mathrm{KNO}_{3}\right)$ increased

leaf $\mathrm{K}$ more rapidly compared to soil-applied fertilizers because plant uptake was much faster, but the positive effect lasts for a shorter time.

Common solid sources of $\mathrm{K}$ applied to citrus groves include the following:

- Potassium chloride (muriate of potash)

- Potassium sulfate

- Potassium-magnesium sulfate

- Potassium nitrate

K nutrient sources used to manufacture true solutions include the following:

- Potassium chloride

- Potassium nitrate

- Potassium sulfate

- Potassium thiosulfate

K nutrient sources applied in foliar sprays include the following:

- Potassium phosphite

- Potassium nitrate

- Potassium thiosulfate

- Monopotassium phosphate

- Dipotassium phosphate 


\section{Conclusion}

Supplying sufficient nutrition should be a high-priority management practice for every grower. An appropriate nutrient balance is necessary to achieve optimum plant nutrition. Correct ratios of nutrients are critical to fertilizer management and sustainability. If an element is below the critical level, yield production falls even though the other elements are kept in sufficient supply. Too much $\mathrm{N}$ with too little $\mathrm{K}$ can reduce fruiting and results in lost crop yield and quality. High $\mathrm{K}$ with low $\mathrm{N}$ and $\mathrm{P}$ supply induces luxury consumption of $\mathrm{K}$, delays fruit development, and reduces juice content. Balanced use of plant nutrients corrects nutrient deficiencies and toxicities, improves soil fertility, increases nutrient- and water-use efficiency, enhances crop yields and fruit quality, develops tolerance to pests, diseases and other stresses, and improves environmental quality. 